\title{
Popularyzacja zasobu Archiwum Narodowego w Krakowie w roku jubileuszowym 100. rocznicy odzyskania przez Polskę niepodległości
}

W 2018 r. Archiwum Narodowe w Krakowie włączyło się w obchody 100. rocznicy odzyskania przez Polskę niepodległości nie tylko jako organizator i współorganizator wystaw jubileuszowych, projektów edukacyjnych oraz okolicznościowych wydawnictw, ale również jako depozytariusz bogatego dziedzictwa dokumentacyjnego, ważnego dla kształtowania się państwa i narodu, i służącego jako źródło inspiracji dla kolejnych pokoleń.

Dla naszej instytucji głównym wydarzeniem obchodów było uhonorowanie wpisem na Polską Listę Krajową Programu UNESCO „Pamięć Świata”, przechowywanego w zasobie krakowskiego Archiwum, zespołu akt Naczelnego Komitetu Narodowego. Uroczystość wręczenia certyfikatów odbyła się 28 września 2018 r. w Belwederze, a towarzyszyła jej wystawa „Pamięć Polski. Dokumenty Niepodległej” prezentująca wyróżnione archiwalia podczas dni otwartych od 29 do 30 września $2018 \mathrm{r}$.

Naczelny Komitet Narodowy powstał w 1914 r. z inicjatywy środowisk politycznych działających na terenie zaboru austriackiego i stał się najwyższą instancją wojskową, skarbową i polityczną w Galicji mającą utworzyć polskie siły narodowe Legiony Polskie, działające u boku armii austriackiej. Przechowywane w zasobie krakowskiego Archiwum akta Naczelnego Komitetu Narodowego są obfitym źródłem do badań nad okresem 1914-1918, ilustrującym dążenia Polaków do odzyskania niepodległości.

Wyróżniony wpisem zespół archiwalny składa się z 949 j.a. liczących kilkaset tysięcy stron. Największą wartość mają akta dokumentujące działalność i program polityczny Naczelnego Komitetu Narodowego stronnictw i ugrupowań, z uwzględnieniem stosunków krajowych i zagranicznych. Cenne są również materiały o treści organizacyjnej i wojskowej.

Archiwum, realizując misję upowszechniania dostępu do dziedzictwa dokumentacyjnego wszystkim zainteresowanym, zakończyło trwający od kilku lat proces digitalizacji tej cennej kolekcji. Kopie cyfrowe akt Naczelnego Komitetu Narodowego są dziś dostępne online poprzez platformę www.szukajwarchiwach.pl. W 2018 r. dzięki współpracy z Wojewódzką Biblioteką Publiczną w Krakowie ruszył proces digitalizacji liczącej ponad 2000 tytułów Biblioteki Legionowej przechowywanej w krakowskim Archiwum. Księgozbiór składa się głównie z publikacji z okresu I wojny światowej i II Rzeczypospolitej związanych z polityką, prawem międzynarodowym, taktyką wojskową, historyczno-wojskową, dokumentujących m.in. Czyn Legionowy. W przeddzień święta 11 listopada udostępniono w Internecie dla czytelników pierwsze 100 tytułów Biblioteki Legionowej w ramach Małopolskiej Biblioteki Cyfrowej (platforma http://mbc.malopolska.pl/).

Liczne wystawy tworzone lub współtworzone przez Archiwum Narodowe w Krakowie pokazywane były nie tylko w Małopolsce, ale z uwagi na ogólnonarodowy charakter przechowywanych w krakowskim Archiwum zbiorów również w wielu miastach na terenie Polski. W 2018 r. powstało 12 nowych wystaw tradycyjnych oraz dwie wirtualne, a także 
prezentowano cieszące się dużą popularnością ekspozycje przygotowane w latach ubiegłych oraz użyczone przez inne instytucje. Pośród tych pierwszych, których Archiwum było organizatorem lub partnerem projektu, warto wymienić: „Z Niewoli do Wolności...” (Archiwum Narodowe w Krakowie); „Kraków był pierwszy... W stulecie odzyskania niepodległości” (Biblioteka Główna AGH), „Z potrzeby serca... Bochnia dla Niepodległej” (bocheński Oddział Archiwum Narodowego w Krakowie), „Kraków dla Niepodległości” (Fundacja Centrum Dokumentacji Czynu Niepodległościowego „Sowiniec”); „Archiwalny Fotoplastikon. Fotografie Krakowa z lat 1918-1939" (Narodowe Archiwum Cyfrowe); czy choćby „Droga do niepodległości. Listopad 1918 r. w Sosnowcu” (Pałac Schoena Muzeum w Sosnowcu). Archiwum współpracowało także przy przygotowaniu wystaw rocznicowych, m.in. z: Muzeum Regionalnym w Dębicy, Muzeum w Chrzanowie, Muzeum Dwory Karwacjanów i Gładyszów w Gorlicach, Muzeum Żup Krakowskich Wieliczka, Fundacją Nomina Rosae Ogród Kultury Dawnej w Nowym Sączu, realizując również projekty w ramach wieloletniego programu „Niepodległa”.

Udział społeczeństwa polskiego w walce o suwerenność poprzez historie lokalne przybliżyła wystawa „Bieżanowian drogi do Niepodległości” (prezentowana w Centrum Kultury Podgórza Dwór Czeczów w okresie 26 października - 12 grudnia 2018 r.). Była to pierwsza odsłona projektu ukazującego pojedyncze osoby i wydarzenia związane z tą małą ojczyzną, które w czasie I wojny światowej uczestniczyły w walce z zaborcami. Wystawa dostępna jest również w wersji online poprzez stronę internetową www.ank.gov.pl. Kolejne elementy tego projektu zaplanowano na 2019 r., tj. film dokumentalny oraz wydanie bogato ilustrowanej monografii zatytułowanej „Udział mieszkańców Bieżanowa w walce o niepodległość w latach 1914-1920”, przygotowanej przez autora projektu i kuratora wystawy Tomasza Wrońskiego, kustosza Archiwum Narodowego w Krakowie.

Obchodząc ten ważny jubileusz, Archiwum od października do listopada gościło również w swoich murach wystawę „Pierwsze dni Niepodległości”, przygotowaną przez Muzeum J. Piłsudskiego w Sulejówku we współpracy z Naczelną Dyrekcją Archiwów Państwowych (dalej: NDAP) i archiwami państwowymi. W ramach promocji polskiego dziedzictwa za granicą krakowscy archiwiści włączyli się w projekty międzynarodowe, m.in. Zbigniew Dyrdoń, kustosz Archiwum Narodowego w Krakowie, współpracując z Biblioteką Polską w Paryżu, opracował wystawę „Walka o granice odrodzonej Polski 1918-1922” („La lutte pour les frontières de la Pologne renaissante 1918-1922").

Projekty edukacyjne to doskonała okazja, by lepiej poznać zapisane w materiałach archiwalnych historie ludzi i wydarzeń, które wiodły nasz kraj ku odrodzeniu i wolności. Z okazji tego wyjątkowego jubileuszu krakowskie Archiwum przeprowadziło liczne lekcje i pokazy archiwalne. Współorganizowano m.in. konkurs dla młodzieży „Jechałem czerwonym tramwajem socjalizmu... Ewolucja myśli politycznej Józefa Piłsudskiego" (ANK Oddział w Nowym Sączu), Grę Miejską Niepodległość (ANK Oddział w Bochni). Przygotowano do druku artykuły i publikacje związane z obchodami jubileuszowymi, a pracownicy Archiwum wygłaszali odczyty i referaty na konferencjach oraz brali aktywny udział w pracach komitetów organizacyjnych, np. w Komitecie Honorowym Obchodów 100. Rocznicy Odzyskania Niepodległości w Powiecie Bocheńskim (Agnieszka Gicala, kierownik Oddziału ANK w Bochni). 
Pokłosiem współpracy wydawniczej z NDAP było przygotowanie do druku oraz wydanie w ramach serii wydawniczej Wielka Wojna - Codzienność Niecodzienności publikacji Śmieszne to życie! Ale go żal.... Dzienniki Kazimierza Filara (Warszawa 2018) oraz wspomnień Antoniego Górszczyka (w opracowaniu Sylwestra Rękasa, kierownika Oddziału ANK w Nowym Sączu, druk 2019 r.). Teksty źródłowe obu tych wydawnictw pochodzą z zasobu Archiwum Narodowego w Krakowie.

Lilianna Pochwalska, Tomasz Wroński Archiwum Narodowe w Krakowie 